\title{
PRAME Gene
}

National Cancer Institute

\section{Source}

National Cancer Institute. PRAME Gene. NCI Thesaurus. Code C127928.

This gene plays a role in the repression of retinoic acid receptor signaling. 